\title{
Globalisation Impacts on Timber Consumption in Slovakia
}

\author{
Hubert Paluš ${ }^{1,}$, Michal Dzian ${ }^{1, *}$, Ján Parobek $^{1}$, and Mikuláš Šupín ${ }^{1}$ \\ ${ }^{1}$ Technical University in Zvolen, Faculty of Wood Sciences and Technology, Department of Marketing, \\ Trade and World Forestry, T. G. Masaryka 24, 96053 Zvolen, Slovak Republic
}

\begin{abstract}
Research background: Globalisation is nowadays phenomenon which affects all economic sectors. The pros and cons of globalisation can also be observed in the case of forestry and forest-based complex in Slovakia. Timber trade and market follows the theory of derived demand, which means that demand for wood depends on the demand for final products. We can observe a significant impact of globalisation on changes in the use of wood from traditional to new ecological and sustainable use. Since 1993 the consumption of industrial roundwood in Slovakia has increased by almost $185 \%$.

Purpose of the article: The aim of this study is to examine the impact of globalisation on the consumption of coniferous and non-coniferous industrial roundwood in Slovakia, and to determine the relationship between the consumption of industrial roundwood and trends of globalisation trends in Slovakia.

Methods: The development of KOF globalization index was analysed in the period 2003 to 2018. In addition, the development of the consumption of coniferous and non-coniferous industrial roundwood was examined. The correlation analysis and linear regression were used to analyse the relationship between the KOF globalisation index and development of consumption of coniferous and non-coniferous industrial roundwood in Slovakia.

Findings \& Value added: The results of correlation analysis show statistically significant relationship between globalisation and the development of consumption of industrial roundwood in Slovakia. We can conclude that the development of globalisation has more significant impact on consumption of non-coniferous industrial roundwood than on consumption of coniferous industrial roundwood.
\end{abstract}

Keywords: KOF globalisation index, wood consumption, globalisation impacts,

JEL Classification: $F 10 ; F 14 ; F 60 ; L 73$

\footnotetext{
* Corresponding author: michal.dzian@tuzvo.sk
} 


\section{Introduction}

In general, the globalization refers to ascending the internationalization of product and service markets, enterprises and industries, technology and competition (Hajdúchová Hlaváčková, 2014). In recent decades, this phenomenon has raised many challenges as well as concerns. The general social concerns have been augmented in the rich countries such as the U.S., France, and Germany, by growing concerns over the economic implications of globalization. Thus, whereas the social concerns are prompted by altruism and empathy, the economic concerns have been the result of fear and self-interest. Bhagwati (2004) addresses these concerns, showing that these are not cogent either. That is why, it is necessary to measure globalisation on the different levels. For instance, Roukanas (2020) measured economic development and the impact of economic globalisation under the prism of global political economy. The concept of economic development was considered broader than the economic growth, which is related to the GDP growth. His study highlights the alterations, which have occurred from the manifestation of the global economic crisis until today. Macroeconomic indicators and international trade volume could be considered as one of the main indicator to measure globalisation. Many authors have focused on the above mention approach (Gunter and Wilcher, 2020; Hammudeh et al., 2020; Shittu et al., 2020; Huh and Park, 2021). Global trade is often captured by trade volume alone. In order to gain a better understanding of the phenomenon, Palan and Simoes, (2021) proposed measures that also account for the interconnectedness of countries, for geographical distance and for the role of individual sectors in bilateral trade. Their results showed substantial increases in all dimensions of globalisation and highlighted the need to analyse globalisation with a comprehensive set of indicators and indicated that trade globalisation for high-tech sectors varies significantly from the evolution seen in other sectors, especially large, low-tech sectors.

Obviously, the globalisation was observed under the concept of sustainable development and in the forest-based sector (Roberts, 2008; Paschalis-Jakubowicz, 2010; Moroz et al., 2021). During last decades the Slovak forest-based industries have been developing, however it is still oriented on the international markets. The domestic consumption of industrial roundwood increased by almost 185\% since 1993 and the roundwood production reached 8.46 mil. $\mathrm{m}^{3}$ in 2019 . Out of this volume 1.36 mil. $\mathrm{m}^{3}$ was subsequently exported abroad. Roundwood exports were oriented mainly to the EU countries (Czech Republic, Austria, Poland, Hungary and Italy) and during the latest years the development of foreign trade in roundwood has shown the positive tendencies of reducing exports and increasing imports. This eliminates the negatives of roundwood exports from Slovakia, which included in particular a relatively high share of exports of higher quality domestic timber (especially assortments of coniferous wood). Value added was thus created abroad and the domestic economy lost tax revenues and revenues from levies (MPSR, 2019). The development of the Slovak economy as well as forest-based industries depends on the foreign markets. Suchomel and Gejdoš (2009) highlighted that an important impact of globalisation on the wood market is reflected in roundwood prices. Their results confirmed that the Slovak economy is open and sensitively react to changes on the global markets. In forestry and forest-based industries, globalization is most visible in timber trade and market follows the theory of derived demand. There is a substantial impact of globalisation on the wood use approach from traditional to new ways. Palus et al. (2007) dealt with the analysis of relevant factors and their influence on the roundwood market. They identified that changes in market relations in forestry-wood chain are determined by globalisation trends, social and environmental issues as well as new possibilities of use of wood material. Moreover, Dzian et al. (2020a) confirmed a significant relationship between the furniture trade and the development of globalisation in Slovakia. It followed that the impact of globalisation on the furniture trade in Slovakia is disputable and globalisation brings positive, as well as negative, impact on economic development. 
Additionally, Dzian et al (2020b) assessed the impacts of globalisation on timber trade in the Slovak Republic. To identify the globalisation impact, the authors applied the KOF globalisation index. Their conclusions indicated a positive linear relationship between the KOF index and timber trade development.

The Slovak timber market as whole economy is open and their development depends on the demand in foreign markets, namely the EU markets. The study examines the impact of globalisation on the consumption of coniferous and non-coniferous industrial roundwood in Slovakia. According to official statistic data this study determines the relationship between the consumption of industrial roundwood and globalisation trends in Slovakia.

\section{Material and Method}

The aim of this paper was to determine the impact of globalisation on the consumption of industrial roundwood in Slovakia. For these purposes, we examined the development of two variables, the KOF Globalisation index and the consumption of coniferous (C) and nonconiferous (NC) industrial roundwood. Both of these variables were observed from 1993 to 2018. Based on the data, it can be seen that volumes of both variables have been increasing in the long time period (see Figure 1). The maximum consumption of coniferous industrial roundwood was observed in 2005. Subsequently, consumption declined by $254 \%$ and reached its minimum value in 2013. This may have been due to the impact of the economic crisis in 2008. The use of coniferous roundwood and products materials are directly influenced by the developments in the construction market. Therefore, due to the construction industry production decline we can observe decrease in consumption of coniferous industrial roundwood. After this significant decline, consumption of coniferous industrial roundwood was on the rise and had increased by $240 \%$ during the last 6 years. In the case of nonconiferous industrial roundwood the development of consumption was more stable. The minimum consumed volume was recorded in 1997 and the maximum in 2015, an increase by $248 \%$.

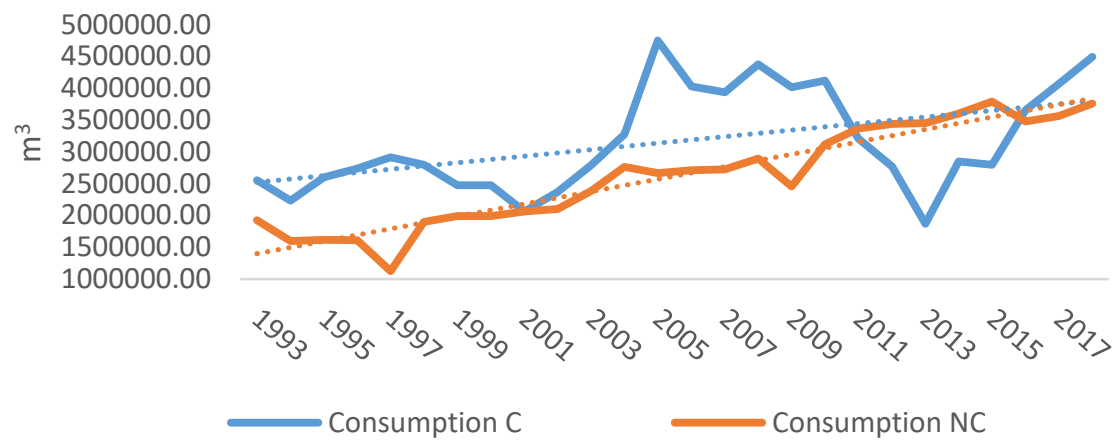

Figure 1. Consumption of Industrial coniferous and non-coniferous round wood in Slovakia

Data of consumption of industrial roundwood were taken from the FAO Stat database. As the FAO Stat database does not contain direct volumes of consumption we used an equation (1) to calculate the missing data.

$$
\text { Consumption }=\text { Production }+ \text { Import }- \text { Export }
$$

As an independent variable the KOF Globalisation Index was used. De Facto KOF globalisation index was used because this index measures actual international flows and activities (Gygli et al., 2019). The data of KOF index were taken from the KOF Swiss 
Economic Institute database (Gygli et al., 2019). Over the last 26 years (from 1993 to 2018), the KOF Globalisation index had increased by $135 \%$.

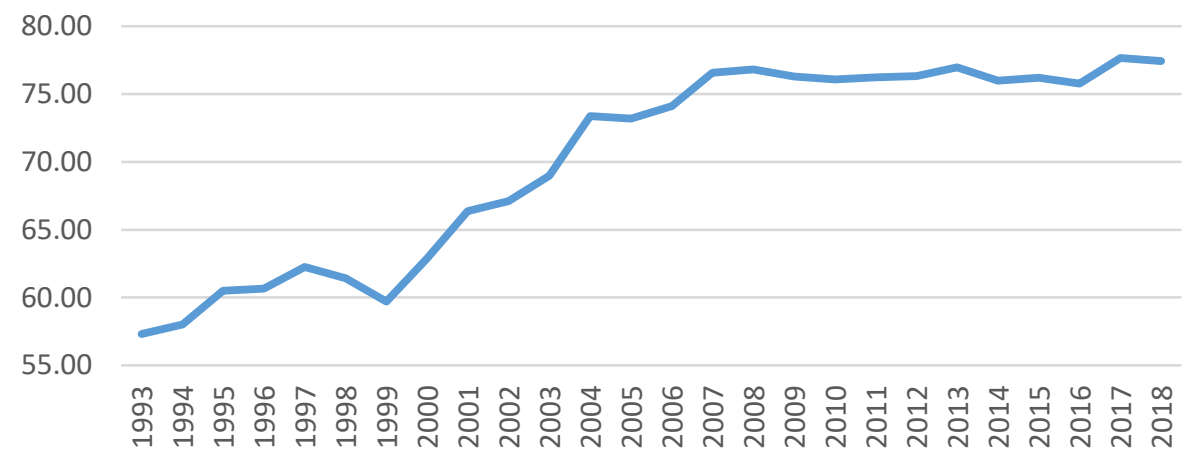

Figure 2. The development of KOF Globalisation Index (De facto) in Slovakia

The linear regression method was used to determine the dependencies between the variables. Two econometrics models were developed. First one for the coniferous industrial roundwood and second one for the non-coniferous industrial roundwood. Based on these models, the relationship between the KOF globalisation index and the development of consumption of industrial roundwood was analysed. The final form of model was defined as follows:

$$
C_{I R W}=f(K O F)
$$

Where $\mathrm{C}_{\mathrm{IRW}}$ is consumption of industrial roundwood and KOF is Globalisation index. On the basis of the above information, a time series model was developed. The general time series model form used is as follows:

$$
\begin{aligned}
& \ln C_{\text {CIRW }_{t}}=\beta_{0}+\beta \ln \mathrm{KOF}_{t}+\varepsilon_{t} \\
& \ln C_{\text {NCIRW }_{t}}=\beta_{0}+\beta \ln K O F_{t}+\varepsilon_{t}
\end{aligned}
$$

Where $C_{C I R W}$ represent development of consumption of coniferous industrial roundwood; $C_{N C I R W}$ is consumption of non-coniferous industrial roundwood; $t$ is year; $\beta_{0}$ is a constant of model; KOF represent development of globalization and it is a vector of explanatory variables; $\varepsilon_{t}$ is the error therm. For the reason that the individual model parameters could be estimated as elasticities, the input data was transformed to logarithms. Variance Inflation Factor and Durbin-Watson test was used to test autocorrelation as well as multicollinearity, respectively. The statistical program SPSS was applied to developed models of consumption of industrial roundwood. In the case of the independent variable KOF, a positive effect on the development of the dependent variable was expected.

\section{Results and Discussions}

Based on the above mentioned methodology, two econometric models of consumption of industrial roundwood were constructed. These models estimated a linear regression between the development of consumption of coniferous and non-coniferous industrial roundwood and KOF globalisation index in Slovakia. The following Table 1 shows the basic statistical characteristics of each model. 
Table 1. Statistical characteristic of models

\begin{tabular}{|c|c|c|c|c|c|}
\hline & Constant & Coefficients & $\mathbf{R}^{\mathbf{2}}$ & $\mathbf{F}$ & $\mathbf{t}$ \\
\hline $\mathrm{C}_{\mathrm{CIRW}}$ & 9.109 & $1.372^{* * *}$ & 0.333 & $12.000^{* * *}$ & $3.464^{* * *}$ \\
\hline $\mathrm{C}_{\mathrm{NCIRW}}$ & 3.494 & $2.647^{* * *}$ & 0.777 & $83.693^{* * *}$ & $2.844^{* * *}$ \\
\hline
\end{tabular}

$\mathrm{C}_{\mathrm{CIRW}}$-consumption of coniferous industrial roundwood; $\mathrm{C}_{\mathrm{NCIRW}}$ - consumption of non-coniferous industrial roundwood; $* * *=\alpha<0.001$;

The final forms of the models in the forms of equations are as follows:

$$
\begin{gathered}
C_{\mathrm{CIRW}}=9,109 K O F^{1,372} \\
C_{N C I R W}=3,494 K O F^{2,647}
\end{gathered}
$$

The results of the statistical analysis indicate a significant relationship between the variables. As it follows from Table 1 we can observe that the development of consumption of non-coniferous industrial roundwood is more affected by globalisation than the development of consumption of coniferous industrial roundwood. KOF globalisation index explains the development of consumption of non-coniferous industrial wood by $78 \%$. The large impact of globalisation is also evident in terms of the value of the coefficient in the model. In the case of non-coniferous roundwood the coefficient can by interpreted as follows: a $1 \%$ increase in globalisation cause a $2.6 \%$ increase in consumption. The impact of globalisation on consumption of coniferous industrial roundwood appears to be less significant. KOF globalisation index explains the development of consumption of coniferous industrial wood by $33 \%$ (at the signaficancy level $\alpha=0,001$ ). In this case a $1 \%$ increase in globalisation causes a $1.4 \%$ increase of consumption of coniferous industrial roundwood. Both, coniferous and non-coniferous consumption of industrial roundwood appeared to be very elastic to KOF globalisation index.

Timber trade and market is very specific. It is affected by a variety of factors that have a direct impact on the demand and supply of roundwood. A typical characteristic of the timber market is the theory of derived demand - the demand for roundwood is derived from the demand for final wood products such as houses, flats, and furniture (Paluš et al., 2018). On the other hand, the supply of roundwood is affected by production factors - incidental felling, the amount of forest land or costs (Dzian, et al. 2020). This study shows that the impact of globalisation also needs to be taken into account. The economic aspects of timber markets and the timber industry have already been affected by the globalisation process. Globalisation brings positive as well as negative impact on timber trade and markets. As pointed (Essmann and Andrian, 2003) according to the criteria of rationalisation and competitive advantage, local economic cycles are being disrupted and, particularly at regional level, economic relations are dissolving and in many segments markets are being suspended. What is generally referred to as the timber chain is breaking down in favour of a global alignment of markets based on supply and demand. The export of roundwood without added value is a very important issue of Slovak timber trade and market (National Forest Centre, 2019). As further pointed out (Essmann and Andrian, 2003) wood based substitutes, such as MDF or OSB boards, have allowed the demand for high quality wood to decrease. Missing production capacities for processing high value assortment of roundwood can be results of these impacts on timber trade in Slovakia. Likewise, missing production capacities is causing an increase of export of roundwood without added value.

However, globalisation also brings some positive aspects. As pointed out (Pelegrinová and Lačný, 2013) there is a positive linear relationship between the globalisation and foreign direct investment. Their results also confirmed a significant relationship between the 
globalisation and GDP per capita. In the case of demand, an important factor which could affect consumption is the purchasing power of the population.

\section{Conclusion}

This study was oriented towards the analysis of the impact of globalisation on the consumption of industrial roundwood. We examined the impact of globalisation on consumption of both coniferous and non-coniferous industrial roundwood. In this study, time series data of the KOF globalization index and the development of industrial roundwood consumption from 2001 to 2018 were analysed. The results show that there is a significant relationship between the KOF globalisation index and the development of consumption of industrial roundwood in Slovakia.

\section{Acknowledgements}

The authors are grateful for the support of the Scientific Grant Agency of the Ministry of Education, Science, Research, and Sport of the Slovak Republic, Grant No. 1/0666/19 Determination of the Development of a Wood-based Bioeconomy and Grant No. 1/0674/19, Proposal of a Model for the Eco-innovation Integration into the Innovation Process of Companies in Slovakia in Order to Increase their Performance, and the Slovak Research and Development Agency, Grant No. APVV-20-0294 Assessment of Economic, Social and Environmental Impacts of Forest Management in Protected Areas in SR on Forestry and Related Industries.

\section{References}

1. Bhagwati, J. (2004). Coping with Anti-globalization. Globalization and the Welfare State. International Political Economy Series, 24-44.

2. Dzian, M., Paluš, H., \& Parobek, J. (2020a). The Impact of Globalisation on the Slovak Timber Trade. Sustainability of forest-based industries in the global economy. Vinkovci, Croatia, 45-49.

3. Dzian, M., Paluš, H., \& Parobek, J. (2020b). The Impact of Globalisation on Valueadded Wood Products Trade. Globalization and its Socio-Economic Consequences 2020, Žilina, Slovak Republic.

4. Essmann, H.-F., \& Andrian, G. (2003). Impacts of globalisation on forestry: considerations on a complex topic. Available at: http://www.fao.org/3/XII/0472C1.htm.

5. Gunter, B. G., \& Wilcher, B. (2020). Three decades of globalisation: Which countries won, which lost? World Economy, 43(4), 1076-1102.

6. Gygli, S., Haelg, F., Potrafke, N., \& Sturm, JE. (2019). The KOF Globalisation Index revisited. Review of International Organizations, 14(3), 543-574.

7. Hajdúchová, I., \& Hlaváčková, P. (2014). Impact of global economy of forestry and forest based industry in the czech and slovak republic. Acta Facultatis Xylologiae Zvolen, 56(2), 135-146.

8. Hammudeh, S., Sohag, K., Husain, S., Husain, H., \& Said, J. (2020). Nonlinear relationship between economic growth and nuances of globalisation with income stratification: Roles of financial development and governance. Economic Systems. Elsevier, 44(3), 100761. 
9. Huh, H.-S., \& Park, C.-Y. (2021). A new index of globalisation: Measuring impacts of integration on economic growth and income inequality. The World Economy, 44(2), 409-443.

10. Moroz, N.Y., Antipova, O.V., Psareva, N.Y., Lyapuntsova, E.V., \& Matveeva, N.S. (2021). Strategies for Sustainable Development of Socio-Economic Systems. Estudios de Economía Aplicada, 39(5).

11. National Forest Centre (2019) Report on the Forest Sector of the Slovak Republic 2018 - GREEN REPORT. Zvolen: Ministry of Agriculture of the Slovak Republic, National Forest Centre.

12. Palan, N., \& Simoes, N. (2021). Measuring fifty years of trade globalisation. The World Economy, 44(6), 1859-1884.

13. Paluš, H., Parobek, J., Dzian, M., \& Supin, M. (2018). Determinants of Sawnwood Consumption in Slovakia. BioResources, 13(2), 3615-3626.

14. Paluš, H., Šulek, R., \& Parobek, J. (2007). Changing market conditions and their impact on roundwood supply chain in the Slovak Republic. COST Conference on Modelling the Wood Chain - Forestry, Wood Industry, Wood Product Markets. Helsinki, Finland, 146151.

15. Paschalis-Jakubowicz, P. (2010). Analysis of selected factors in the processes of globalization and their impact on global trends in forestry. III. Role, place and importance of forests and forestry in a global perspective. Sylwan, 154(3), 147-159.

16. Pelegrinová, L., \& Lačný, M. (2013). Analýza vplyvu globalizačných procesov na ekonomiky vyspelých krajín. Annales Scientia Politica, 2(2), 27-35.

17. Roberts, D. G. (2008). Globalisation and its implications for the Indian forest sector. International Forestry Review, 10(2), 401-413.

18. Roukanas, S. (2020). Measuring economic development and the impact of economic globalisation. Studies in Business and Economics, 15(3).

19. Shittu, W.O., Yusuf, H.A., El Houssein, A.E., \& Hassan, S. (2020). The impacts of foreign direct investment and globalisation on economic growth in West Africa: examining the role of political governance. Journal of Economic Studies, 47(7), 17331755.

20. Suchomel, J., \& Gejdoš, M. (2009). Analýza vývoja cien vybraných sortimentov surového dreva a výrobkov z dreva. Financovanie 2009 Lesy-drevo. Zvolen: Technická univerzita vo Zvolene. 